\title{
Comparison of new immunofluorescence method for detection of soy protein in meat products with immunohistochemical, histochemical, and ELISA methods
}

\author{
Michaela Petrášová, Matej Pospiech, Zuzana Řezáčová Lukášková, Bohuslava Tremlová \\ University of Veterinary and Pharmaceutical Sciences Brno, Faculty of Veterinary Hygiene and Ecology, \\ Department of Vegetable Foodstuffs Hygiene and Technology, Brno, Czech Republic
}

Received December 3, 2013

Accepted July 23, 2014

\begin{abstract}
Soy proteins are commonly used in the food industry thanks to their technological properties. However, soy is, along with cow's milk, eggs, wheat, peanuts, tree nuts, fish, crustaceans, and molluscs, responsible for around $90 \%$ of food allergies, and is also one of the foodstuffs that can cause anaphylaxis. The aim of this work was to compare the immunofluorescence method for the detection of soy protein in meat products purchased from the retail market with other microscopic methods (immunohistochemical and histochemical), with the ELISA reference method and with the confirmatory results. Within the research, 127 meat products purchased in the retail network were examined using the immunofluorescence method used for the detection of soy protein. The method was compared to Enzyme-Linked ImmunoSorbent Assay (ELISA), immunohistochemical, and histochemical methods. According to McNemar's test, noncompliance between the immunofluorescence method and immunohistochemical method was low. In addition, a significant difference between the fluorescence method and ELISA $(P<0.05)$ and a highly significant difference between the fluorescence method and histochemical examination $(P<0.01)$ was found. The immunofluorescence method was also compared with confirmatory results. According to McNemar's test, non-compliance between the immunofluorescence method and confirmatory results was low. The results showed the possibilities of this new method to detect the content of soy protein in meat products.
\end{abstract}

Fluorescence microscopy, meat products, soybean, foodstuffs, allergy

Soy protein is added to meat products due to its unique functional properties, such as water and fat absorption, creating texture and emulsifying ability. On the other hand, in the United States alone, soybean ranks among 8 major food allergens and has been credited with more than $90 \%$ of food borne allergies (Kabourek and Taylor 2003). Estimates of thresholds inducing undesirable reactions in persons allergic to soy protein differ significantly and values between 0.0013 and $500 \mathrm{mg}$ have already been published (Becker et al. 2004; Ballmer-Weber et al. 2007). Clinical manifestations of soy allergies include digestive problems, respiratory diseases (rhinitis, asthma), skin reactions (urticaria, atopic eczema), and IgE-mediated systemic reactions (Batista et al. 2007). The issue of food allergens is enshrined in the legislation of the European Union, namely in Directive 2003/89/EC amending Directive 2000/13/EC as regards indication of the ingredients present in foodstuffs. In order to avoid misleading consumers and also to protect allergic consumers, analytical methods for determination of soy protein in meat products have been developed. Most of these methods are based on the electrophoretic, immunochemical or chromatographic techniques. The reference method used in determination of soy protein in products is the immunochemical method ELISA. Other options are microscopic methods which were for the purposes of soy protein detection in meat products combined with staining techniques: Gömöry staining, modified by Grocott, or trichrome staining by Charvát (Heckmann et al. 1992). Among microscopic methods for detecting plant proteins, the most reliable are immunohistochemical methods. These methods were used 
for detection of soy protein in the study Boutten et al. (1999) or Pospiech et al. (2009). However, it appears that for each commodity and allergen it is necessary to optimize the testing protocol so as to provide sufficient sensitivity and reliability.

Another option for soy protein detection is the immunofluorescence methods which belong among highly sensitive and specific methods and can therefore be used in complex food matrices (Griesbeck 2004).

The aim of this work was to compare the immunofluorescence method for the detection of soy protein in meat products purchased from the retail market with other microscopic methods (immunohistochemical and histochemical), with the ELISA reference method and with the confirmatory results.

\section{Material \\ Materials and Methods}

The subjects of examination were 127 heat-processed meat products (pork and beef) purchased in the Czech Republic. Three samples of $1 \mathrm{~cm}^{3}$ were taken from all the meat products and fixed in formaldehyde. For the ELISA method, a sample of $250 \mathrm{~g}$ was taken. Sampling was performed so as to cover the entire meat product (middle and both end parts of the product always from the centre and under-cover layer).

\section{Sample treatment and preparation}

The samples for microscopic examination were processed in the histology laboratory at the Department of Hygiene and Technology of Vegetable Foodstuffs, Faculty of Veterinary Hygiene and Ecology, University of Veterinary and Pharmaceutical Sciences Brno. After fixation, the samples were dehydrated in an ascending series of alcohol (30-96\%) and acetone (RNDR. Jan Kulich s. r. o., Prague, Czech Republic) in Autotechnikon AT-4 and mounted in paraffin blocks in Paraplast (RNDR. Jan Kulich s. r. o., Prague, Czech Republic), which were sliced in a sliding microtome of Microm HM 400 (Leica Microsystems GmbH Wetzlar, Germany) into $4 \mu \mathrm{m}$ thick sections with trimming of $50 \mu \mathrm{m}$. Sections were stretched on the water surface and mounted on Super-Frost Plus slides (Menzel-Gläser, Germany).

\section{Immunofluorescence detection}

The immunofluorescence detection method was performed according to the following procedure. The method is based on the IHC principle described by Pospiech et al. (2009) who confirmed the suitability of primary antibody for IHC analysis of soy protein in food matrix. Sections were immersed in: (1) xylene twice for 10 min; (2) absolute ethanol (Moravský Lihovar, Kojetín, Czech Republic) twice for $10 \mathrm{~min}$, followed by $90 \%$ and subsequently by $70 \%$ aqueous ethanol (v/v) $10 \mathrm{~min}$ each bath; (3) tap water for $7 \mathrm{~min}$; (4) distilled water for $7 \mathrm{~min}$; (5) PBS - Phosphate Buffered Saline, $80 \mathrm{~g} / 1 \mathrm{NaCl}, 2 \mathrm{~g} / 1 \mathrm{KCl}, 2 \mathrm{~g} / 1 \mathrm{KH}_{2} \mathrm{PO}_{4}, 23.4 \mathrm{~g} / 1 \mathrm{Na}_{2} \mathrm{HPO}_{4} \cdot 2 \mathrm{H}_{2} \mathrm{O}, 0.16 \mathrm{~g} / 1 \mathrm{NaOH}$ adjusted to $\mathrm{pH}$ 7.4; (6) citrate buffer $-21 \mathrm{~g} / 1 \mathrm{C}_{6} \mathrm{H}_{8} \mathrm{O}_{7}, 9 \mathrm{~g} / 1 \mathrm{NaOH}$ adjusted to $\mathrm{pH} 6$ for $5 \mathrm{~min}$ at $650 \mathrm{~W}$ in a microwave; (6) PBS for $5 \mathrm{~min}$; (7) $3 \%(\mathrm{v} / \mathrm{v}) \mathrm{H}_{2} \mathrm{O}_{2}$ in PBS for $30 \mathrm{~min}$ and then (8) PBS twice for $5 \mathrm{~min}$. The sections were then incubated successively: (9) for $30 \mathrm{~min}$ at $25^{\circ} \mathrm{C}$ with $5 \%(\mathrm{v} / \mathrm{v})$ goat normal serum in PBS (Vector Laboratories, Burlingame, GB); (10) for $12 \mathrm{~h}$ at $8{ }^{\circ} \mathrm{C}$ with an anti-soy antibody (Sigma-aldrich, ref. S2519-1ML, USA) diluted 1:500 with antibody diluent (DakoCytomation ref. S0809, Glostrup, Denmark) and washed in PBS twice for 5 min; (11) for 30 min at $25^{\circ} \mathrm{C}$ with $25 \mu \mathrm{l}$ per section of anti-rabbit biotinylated antibody (Vector Laboratories, PK 6101, Burlingtone, USA) and than in PBS twice for $5 \mathrm{~min}$; (12) washed in PBS for $5 \mathrm{~min}$; for $15 \mathrm{~min}$ at $25^{\circ} \mathrm{C}$ with Texas Red (Vector Laboratories, product No. Burlingame, GB) 1:250 with PBS, and washed in PBS twice for 5 min. The sections were mounted with Vectashield mounting medium for fluorescence (Vector Laboratories, Burlingame, GB) and micro coverslips were laid onto each section. All unmarked chemicals and solutions were from RNDr. Jan Kulich s. r. o., Prague, Czech Republic and were used in p.a. quality.

\section{ELISA, immunohistochemical and histochemical examination}

ELISA examination was performed at the Veterinary Research Institute, Brno. Immunohistochemical examination of samples was done in histological laboratories at the University of Veterinary and Pharmaceutical Sciences Brno. The procedures were performed according to Pospiech et al. (2009). Histochemical examination was performed according to the procedure by Pospiech et al. (2011).

\section{Confirmatory result}

As confirmatory results, those results were used which were based on the following hypothesis. The product containing soy protein according to the results of at least three out of four of the diagnostic methods was evaluated as positive to the content of soy protein. If the results of at least three methods were negative, the product was evaluated as negative to the content of soy protein.

Evaluation of results

Within the microscopic examination, 9 sections were examined for each sample at magnifications of $\times 100$ 
and $\times 200$ using the flourescence microscope of Leica DM 3000. Digitization of samples was performed by the Leica DFC 295 camera and software Leica Application Suite, Advanced Fluorescence 2.6.0.7266 support by the program of Leica LAS AF. Sections of immunohistochemical and histological examination were investigated without inserting a filter in the visible light spectrum and sections for immunofluorescence were examined with the I3 filter which has excitation at $510 \mathrm{~nm}$ (Plate II, Fig. 1).

Results obtained from immunofluorescence method were compared with results from ELISA, immunohistochemistry, histochemistry and the confirmatory results. The results were evaluated qualitatively with the symbols of,+- and a doubtful result of $+/$. Doubtful results were evaluated by + and - in the statistical processing. Within the immunofluorescence test, the result in which the antibody was not sufficiently bound to soybean protein and it was difficult to detect it due to weak fluorescence intensity, was considered a doubtful result.

\section{Statistical analysis}

Statistical analyses were performed using the Unistat program 6.1 for MS Excel (Unistat Ltd., 2012, Czech Republic). Significant differences between methods where calculated using the McNemar's test. Differences were considered significant at $P<0.05$.

\section{Results}

Table 1. Matching ratio between the fluorescent method and other methods used for detection of soy protein in 127 samples of meat products.

The aim of the study was to compare the immuno-

\begin{tabular}{lc}
\hline Method & $\begin{array}{c}\text { Compared with } \\
\text { the immunofluorescence method (\%) }\end{array}$ \\
\hline Enzyme-Linked ImmunoSorbent Assay & 75.40 \\
Histological method & 65.89 \\
Immunohistochemical method & 92.06 \\
Confirmatory result & 92.06
\end{tabular}

Notes: Percentage shows how many results from the examination of 127 samples were the same for two compared methods.

Table 2. Percentage of doubtful results for individual methods used for detection of soy protein in 127 samples of meat products.

\begin{tabular}{lc}
\hline Method & Percentage of doubtful results \\
\hline Enzyme-Linked ImmunoSorbent Assay & 13.39 \\
Histological method & 15.87 \\
Immunohistochemical method & 5.51 \\
Immunofluorescence method & 2.36 \\
Confirmatory result & 0.00 \\
\hline
\end{tabular}

Table 3 . Contingency table $(2 \times 2)$ for comparison of the immunofluorescence method with the confirmatory results used for detection of soy protein in 127 samples of meat products.

\begin{tabular}{lcc}
\hline & Immunofluorescence + & Immunofluorescence - \\
\hline Confirmatory resuts + & 110 & 8 \\
Confirmatory results - & 4 & 8 \\
Chi-square statistic & 1.333333333 & \\
Right-tail probability & 0.25 & \\
\hline
\end{tabular}
fluorescence with other methods for determination of soy protein. The analysis included 127 meat products that are likely to contain soy protein. Table 1 presents the percentage conformity of immunofluorescence method with results from other methods.

Correspondence of immunofluorescence examination with immunohistochemical detection was $92.06 \%$ and agreement with the ELISA method was $75.4 \%$.

Between the fluorescence method and the confirmatory results no significant $(P>0.05)$ difference was found (Table 3 ).

The same result was achieved by comparing the fluorescence method with immunohistochemical method where there was no significant $(P>0.05)$ difference (Table 4).

By comparing the immunofluorescence method and ELISA assay a significant $(P<0.05)$ difference was found (Table 5).

The difference between 
Table 4. Contingency table $(2 \times 2)$ for comparison of the immunofluorescence method with the immunohistochemical method used for detection of soy protein in 127 samples of meat products.

\begin{tabular}{lcc}
\hline & Immunofluorescence + & Immunofluorescence - \\
\hline Immunohistochemical + & 113 & 3 \\
Immunohistochemical - & 8 & 14 \\
Chi-square statistic & 2.272727273 & \\
Right-tail probability & 0.13 & \\
\hline
\end{tabular}

Table 5 . Contingency table $(2 \times 2)$ for comparison of the immunofluorescence method with the Enzyme-Linked ImmunoSorbent Assay method used for detection of soy protein in 127 samples of meat products.

\begin{tabular}{lcc}
\hline & Immunofluorescence + & Immunofluorescence - \\
\hline Enzyme-Linked & 114 & 11 \\
ImmunoSorbent Assay + & & 10 \\
Enzyme-Linked & 26 & \\
ImmunoSorbent Assay - & 6.081081081 & \\
Chi-square statistic & 0.01 & \\
Right-tail probability & & \\
\hline
\end{tabular}

Table 6 . Contingency table $(2 \times 2)$ for comparison of the immunofluorescence method with the histochemical method used for detection of soy protein in 127 samples of meat products.

\begin{tabular}{lcc}
\hline & Immunofluorescence + & Immunofluorescence - \\
\hline Histochemical + & 98 & 9 \\
Histochemical - & 34 & 11 \\
Chi-square statistic & 14.53488372 & \\
Right-tail probability & 0.00 & \\
\hline
\end{tabular}

the methods of immunofluorescence and histochemical examination was even highly significant $(P<$ 0.01) (Table 6).

\section{Discussion}

The correspondence of imunofluorescence examination with immunohistochemical (IHC) detection was $92.06 \%$. Differences between the two methods that have the same base (antibody binding to the antigen in histological sections) are caused by higher sensitivity of the fluorescence method. This fact was also reflected in a lower percentage of doubtful results than in $\mathrm{IHC}$ (Table 2), which, due to the mode of statistical analysis caused an $8 \%$ discrepancy between the methods.

Doubtful results may occur, for example, by false negativity, false background staining, low concentrations of soy protein in the product or a low antibody binding to soy protein, for example, due to the heat treatment. The correspondence of immunofluorescence examination with the ELISA method was $75.4 \%$. A higher percentage of agreement might be expected due to a similar principle of these two methods (antibody binding to the antigen), but ELISA indicated a higher percentage of doubtful results (Table 2).

The immunofluorescence method reached different results compared to ELISA and histochemical examination methods. The ELISA method has been adopted as the reference method of AOAC International for the determination of soy protein in raw and cooked meat products (since 1988). Therefore, this method is commonly used in food laboratories (AOAC 1998). However, based on our results the probability of agreement between ELISA and immunofluorescence method is small. The same is true for the results of histochemical examination, in which the detection is performed based on different colors and characteristic morphology of the protein. Using conventional staining procedures, soy protein behaves similarly to protein of muscle fibres and thus detection is difficult (Tremlová and Štarha 2002). Another complication is the different shape of various kinds of soy protein. In histochemical examination, only finding structural elements, such as the 
palisade and goblet cells (Horn 1987), or in case of soy flour finding oxalate crystals in the cells of soybean (Strass burger 1971) can be seen as clear determination. In contrast, the immunofluorescence method uses antigen-antibody binding with the mark antibody and fluorescence of soy protein on a black background and this allows identification without finding specific structural elements of soybeans.

Comparison with other methods shows that the immunofluorescence method is comparable to the immunohistochemical method, as well as to the confirmatory results where no significant difference $(P>0.05)$ was recorded. Another important fact for a successful application in practice is that the immunofluorescence method achieved a lower percentage of doubtful results in comparison with the immunohistochemical method. A significant difference $(P<0.05)$ was demonstrated between the immunofluorescence method and the immunochemical ELISA method and a highly significant difference $(P<0.01)$ in comparison with the histochemical method.

\section{Acknowledgments}

The research was supported by the project IGA 2/2012/FVHE.

\section{References}

AOAC 1998: Official Method 998.10, Soy protein in raw and heat-processed meat products, enzyme-linked immunosorbent assay. In: Official methods of analysis, $16^{\text {th }}$ ed., rev. 1998. Gaithersburg, MD: AOAC International.

Ballmer-Weber BK, Holzhauser I, Scibilia J, Mittag D, Zisa G, Ortolani C, Oesterballe M, Poulsen LK, Vieths S, Bindslev-Jensen C 2007: Clinical characteristics of soybean allergy in Europe: a double-blind, placebocontrolled food challenge study. J Allergy Clin Immunol 119: 1489-1496

Batista R, Martins I, Jenő P, Pinto-Ricardo C,Margarida-Oliveira M 2007: A proteomic study to identify soya allergens - the human response to transgenic versus nontransgenic soya samples. Int Arch Allergy Immunol 144: $29-38$

Becker W, Brasseur D, Bresson JL, Flynn A, Jackson AA, Lagiou P, Mingrone G, Moseley B, Palou A, Przyrembel H, Salminen S, Strobel S, van Loveren H 2004: Opinion of the scientific panel on dietetic products, nutrition and allergies on a request from the commission relating to the evaluation of allergenic foods for labelling purposes (Request nr EFSA-Q-2003-016). EFSA J 32: 1-197

Boutten B, Humbert C, Chelbi M, Durand P, Peyraud D 1999: Quantification of soy proteins by association of immunohistochemistry and video image analysis. Food Agric Imunol 11: 51-59

Directive 2000/13/EC of the European Parliament and of the Council of 20 March 2000 on the approximation of the laws of the Member States relating to the labelling, presentation and advertising of foodstuffs. Official J L 109: 29-42

Griesbeck O 2004: Fluorescent proteins as sensor for cellular functions. Curr Opin Neurobiol 14: 636-641

Heckmann T, Neumann B, Tschirdewahn B, Bentler W 1992: Soy protein. Proof in raw sausage and cooked sausage. Fleischwirtschaft 72: 1423-1427

Horn D 1987: The detection of plant protein preparations in meat products with histological examination procedures. Fleischwirtschaft 67: 616-618

Kabourek JL, Taylor SL 2003: Soy foods and allergies: separating fact from fiction. Soy Connect 11: 1-6

Pospiech M, Tremlová B, Renčová E, Randulová Z 2009: Immunohistochemical detection of soya protein optimisation and verification of the method. Czech J Food Sci 27: 11-19

Pospiech M, Tremlová B, Rencová E, Randulová Z, Řezáčová Lukášková Z, Pokorná J 2011: Comparison of the results of the ELISA, histochemical, and immunohistochemical detection of soya proteins in meat products. Czech J Food Sci 29: 471-479

Strassburger E. Textbook of Botany, 30 ${ }^{\text {th }}$ ed. Stuttgart, Gustav Fischer Verlaf, 1971, 1171 p.

Tremlová B, Štarha P 2002: The assessment of histological methods for the detection of plant ingredients in meat products with regard to the application of the image-analysis system. In: 43. Arbeitstagung des Arbeitsgebietes „Lebensmittelhygiene“. Garmisch, Partenkirchen, pp. 838-842 
Plate II

Petrášová M. et al.: Comparison... pp. S65-S69

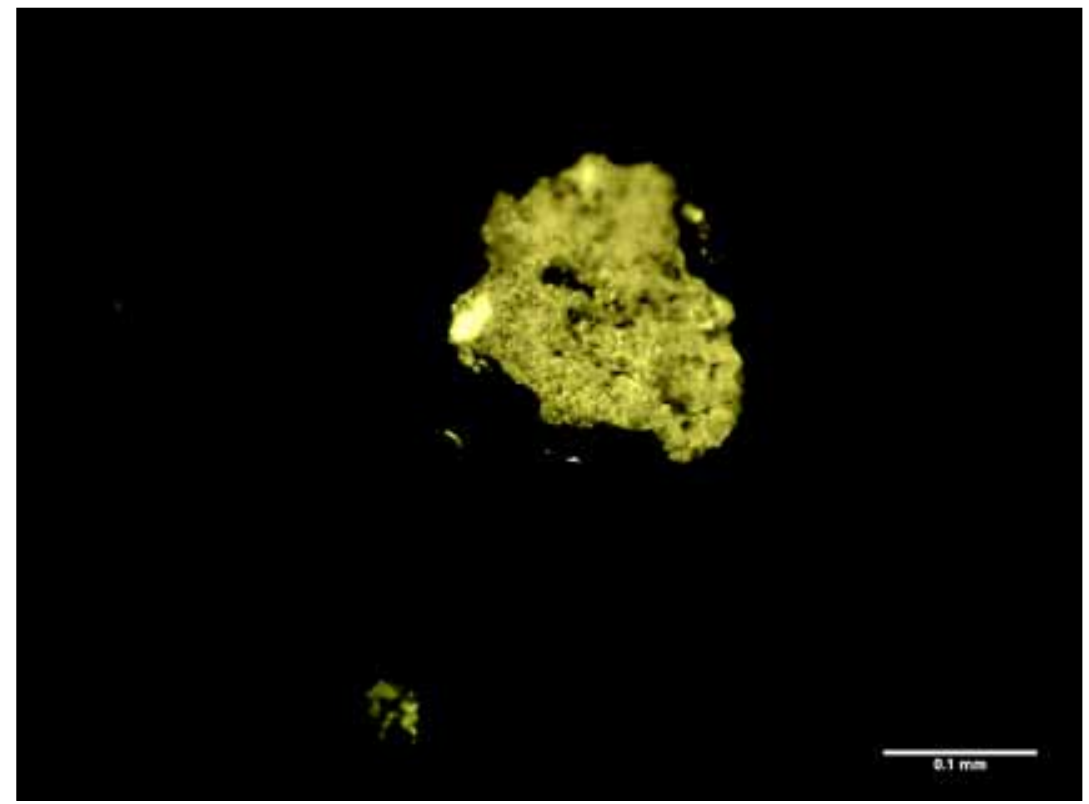

Fig. 1. Soy protein (yellow) in meat products (black). Immunofluorescence method, $\times 100$ magnification. 